It goes without saying, this has been a terrible shock. But I can also say that I think these last few years were the best of Iliya's life-certainly our life together-in many ways; he felt and looked fine the night of his death, anticipating tennis the next day. Death came very quickly, in his sleep.

We celebrate Iliya's life and are grateful to him for his numerous contributions, his insights on so much of the Arab world; we remember his humor, his kindness, his love of family and friends.

Allah yarhamu.

Denis J. Sullivan

Northeastem University

\title{
Stanford J. Shaw (1930-2006)
}

Stanford J. Shaw was born in St. Paul, Minnesota on May 5, 1930. He died in Ankara, Turkey on December 15, 2006 at the age of 76 . He is survived by his wife, Ezel Kural Shaw, and his daughter, Wendy Miriam Kural Shaw.

Professor Shaw received his BA and MA from Stanford and his PhD from Harvard. After eight years as assistant and associate professor at Harvard, he went to UCLA as Professor of Turkish History in 1968. He retired from UCLA in 1992, but continued to teach there as an emeritus professor until 1997. In 1999 he joined the faculty of Bilkent University in Ankara.

Shaw was one of the first to base his work on in-depth study in Middle East archives. His first works-The Financial and Administrative Organization and Development of Ottoman Egypt (Princeton, 1962), Ottoman Esypt in the Eighteenth Century (Cambridge, 1962), Ottoman Egypt in the Age of the French Revolution (Cambridge, 1964), and The Budget of Ottoman Egypt (The Hague, 1968) drew upon the Egyptian and Ottoman Archives. In 1971, with Between Old and New: The Ottoman Empire under Sultan Selim III (Cambridge, 1971), Shaw began the study of Ottoman and Turkish history that was to continue until his death. Along with Turkish scholars such as Hâlil İnalckk and Hâlil Sahillioğlu, Shaw pioneered the use of archival documents to bring an Ottoman dimension to a history that had previously been based on reports of consuls, missionaries, and other Westerners. His two-volume textbook, History of the Ottoman Empire and Modern Turkey (Cambridge, 1995) (the second volume co-authored by Ezcl Kural Shaw) has a place on the shelf of every serious historian of the Ottoman Empirc. It was followed by detailed histories of Ottoman Jewry: The Jews of the Ottoman Empire and the Turkish Republic (New York, 1992), and Turkey and the Holocaust (New York, 1993) and a multi-volume history of the Turkish War of Independence, From Empire to Republic (Ankara, 2001). At his death his work was far advanced on a history of the Ottoman Empire in World War I.

Professor Shaw received virtually all the honors that could come to one in his field, including fellowships from the Guggenheim Foundation, the National Endowment for the Humanities, the Royal Institute of International Affairs, the Social Science Research Council, and Fulbright-Hays. Boğaziçi University and Harvard both awarded him honorary degrees. The President of Turkey awarded him the Turkish Medal of Honor, and he received honors from the Turkish Historical Association and other Turkish and American organizations. He was the first editor-in-chief of the International Journal of Middle East Studies, serving in that position from 1970 to 1980.

At Harvard and UCLA Professor Shaw instructed a generation of students in Ottoman history. His undergraduate class on the Ottomans normally attracted more than 500 students, an unheard of 
number in a non-Western history course. Those of us who studied with him for our graduate degrees were expected to undergo all the usual language classes and history courses, but he also gave us a thorough grounding in archival Ottoman Turkish and archival research that madc possible our own later research. He realized that historians needed more than a literary background, so we studied handwritten Ottoman administrative documents. At the time, before Professor Inalcek came to the University of Chicago, this was unknown in the United States. When Shaw's students arrived at the Ottoman Archives they could begin to work immediately.

While Professor Shaw himself studied with traditional scholars such as Hamilton Gibb and Lewis Thomas, he was open to new ideas among his students. At a time when advisors were often still selecting thesis topics for their doctoral candidates, Shaw was willing to let his students attempt theses on fields such as Middle Eastern historical demography. He was not completely sure they would be successful, but he let them take the chance. For someone, such as myself, who did not fit well with the traditional study of Ottoman history, he was the perfect advisor-teaching the history, providing the tools for research, and helping to find financial support but allowing the freedom to take new paths.

All of us who studied with Professor Shaw owe him a great debt. We remember him not only as a scholar, but as a kind and a good man.

Justin A. McCarthy Uniwersity of Louisville 